\title{
Metil paration bileşiğinin paraoksonaz enzimi üzerine inhibisyon etkisinin araştırılması
}

\author{
Nahit GENÇER* \\ Balıkesir Üniversitesi, Fen Edebiyat Fakültesi, Kimya Bölümü, Çă̆ış Kampüsü, Balıkesir \\ Geliş Tarihi (Received Date): 07.02.2019 \\ Kabul Tarihi (Accepted Date): 14.03.2019
}

\section{Özet}

Bu çalışmada, amonyum sülfat çöktürmesi ve Sepharose-4B-L-tirosin-1-aminoantresen jelini içeren hidrofobik etkileşim kromatografisi tekniği kullanılarak insan paraoksonaz (PON1) enzimi saflaştırılmıştır. Saflaştırılan PON1 enziminin saflık kontrolü SDS poliakrilamid jel elektroforezi ile yapılmıştır. Saflaştırma oranı 663 olarak bulunmuştur. Daha sonra saf enzim üzerine metil paration zirai ilacının inhibisyon etkisi incelenmiştir. Söz konusu ilacın IC50 değeri 1,41 mM bulunmuştur.

Anahtar kelimeler: Paraoksonaz, saflaştırma, metil paration.

\section{Investigation of the effect of methyl parathion on the paraoxonase enzyme}

\begin{abstract}
In this study, human paraoxonase (PON1) enzyme was purified by using the hydrophobic interaction chromatography technique including ammonium sulfate precipitation and Sepharose-4B-L-tyrosine-1-aminoantresan gel. The purity control of purified PON1 enzyme was performed by SDS polyacrylamide gel electrophoresis. Purification rate was found to be 663. Then, the inhibition effect of methyl parathion on pure enzyme was investigated. The IC50 value of this compound was $1.41 \mathrm{mM}$.
\end{abstract}

Keywords: Paraoxonase, purification, methyl parathion.

*Nahit GENÇER, ngencer@balikesir.edu.tr, http://orcid.org/0000-0001-7092-8857 


\section{Giriş}

Paraoksonaz enzimi (EC 3.1.8.1, PON1) karaciğer tarafindan sentezlenmektedir. Yapısal ve katalitik kalsiyum olmak üzere iki adet metal iyonu içeren bir esterazdır. Serumda, yüksek yoğunluktaki lipoproteinlere bağlı olarak bulunur [1]. PON1 enziminin şimdiye kadar üç farklı fonksiyona sahip olduğu tespit edilmiştir. Birincisi; PON1 enzimi organofosfat ajanları ve sinir gazlarını hidroliz ederek detoksifikasyonda önemli rol oynar. İkincisi; LDL'nin oksidasyonu ile lipit peroksitlerin oluşumuna karş1 koruyucu etkisi ile antioksidan özelliği vardır. Üçüncüsü; bakterilerin birbiri ile iletişimini sağlayan lakton bileşiklerini hidroliz ettiği için laktonaz aktivitesi ile ayrıca önem taşımaktadır [2, 3].

Zirai tarım ilacı olarak da bilinen pestisit deyimi, 1-insektisit (böcek öldürücü), 2herbisit (yabani ot öldürücü), 3-fungusit (küf öldürücü), 4-rodentisit (kemirgen öldürücü) vb. şeklinde sınıflandırılmaktadır. Bilinçsiz pestisit kullanımının sonucunda gıdalarda pestisit kalıntıları olur ve bunlar insanlar üzerinde olumsuz etkiler gösterebilir. Pestisitlerin kanserojen etkileri olduğu saptanmıştır [4].

Metil paration, tarım alanında ve zararlı böceklerin yok edilmesinde geniş çapta kullanılan bir insektisit olup her yıl çok sayıda insan çeşitli sebeplerden dolayı metil parationa maruz kalmaktadır. Bu bileşik Akdeniz Bölgesi’nde özellikle tarımsal alanda çok fazla miktarda kullanılan bir insektisittir [5].

Bu çalışmada, amonyum sülfat çöktürmesi ve Sepharose-4B-L-tirosin-1-aminoantresen jelinden oluşan hidrofobik etkileşim kromatografisi (HEK) tekniği kullanılarak PON1 enziminin saflaştırılması ve metil parationun bu enzim üzerine inhibisyon etkisinin belirlenmesi amaçlanmıştır.

\section{Materyal metod}

\subsection{Kan serumunun ayrilmast}

Gönüllü kişilerden alınan kanlar $5000 \mathrm{rpm}$ 'de, $+4^{\circ} \mathrm{C}$ 'de ve 15 dakika santrifüj edilerek serumları ayrıldı. Bu serumlar deneysel çalışmalarda kullanılmıştır.

\subsection{Enzim aktivite tayini}

Aktivite ölçümü için $50 \mu \mathrm{L}$ enzimi tampon çözeltisine $(900 \mu \mathrm{L}, 0,1 \mathrm{M}$ trise-baz, $\mathrm{pH}: 8,0$ ve $100 \mu \mathrm{L}, 1 \mathrm{mM}$ paraoksan) çabuk bir şekilde eklendikten sonra $412 \mathrm{~nm}$ 'de bir dakikadaki absorbansta meydana gelen artış tespit edildi [6]. Bu sayede paraoksan substratının hidroliz hızı tespit edildi. Aynı işlem enzim olmadan tekrarlandı ve aradaki fark enzim aktivitesi olarak hesaplandı. Bir dakikada oluşan p-nitrofenolün mikromolü bir ünite olarak kabul edildi.

\subsection{Amonyum sülfat çöktürmesi (AMS)}

$\mathrm{Bu}$ amaçla literatürde daha önce belirlenmiş olan \%60-80 aralığında amonyum sülfat çöktürme işlemi gerçekleştirildi [7]. 


\subsection{Hidrofobik jel sentezi}

Enzimi saflaştırmak için kullanılan hidrofobik jel üç aşamada sentezlendi. İlk olarak, Sepharose 4B üzerindeki hidroksil grupları siyanojen bromür ile aktive edildi. Bir sonraki aşamada, $\mathrm{CNBr}$ kullanılarak aktive edilen Sepharose-4B ile L-tirozin'in reaksiyonu sonucu Sepharose-4B-L-tirozin jeli elde edildi. Son olarak, diazolanmış 1aminoantresan Sepharose 4B- L-tirozine bağlanmasıyla hidrofobik matris sentezlendi.

\subsection{Enzimin saflaştırılması}

Sepharose-4B-L-tirosin-1-aminoantresen jeli içeren kolon $1 \mathrm{M}(\mathrm{NH} 4)_{2} \mathrm{SO}_{4}$ içeren $0,1 \mathrm{M}$ Tris- $\mathrm{HCl}(\mathrm{pH}: 8,0)$ çözeltisiyle dengelendi ve bu kolona sözkonusu enzimi içeren serum örneği tatbik edildi. Kolona yüksek tuz konsantrasyonundan düşük tuz konsantrasyonuna doğru tuz gradienti uyguland. PON1 enzimi $0,1 \mathrm{M}$ Tris-HCl pH:8,0 solüsyonu ile 1,5 mL'lik fraksiyonlar şeklinde elue edildi.

\subsection{Bradford yöntemiyle kantitatif protein tayini}

Protein miktarları Bradford metoduna göre $595 \mathrm{~nm}$ 'de spektrofotometrik olarak belirlendi. Bu işlemde serum albumin standart olarak kullanıldı [8].

\subsection{SDS poliakrilamid jel elektroforezi (SDS-PAGE)}

PON1 enziminin HEK ile saflaştırılmasından sonra iki farklı akrilamid derişiminde; yığma jeli \% 3 ve ayırma jeli \% 10 olacak şekilde SDSPAGE Laemmli yöntemi ile enzimin saflık derecesi kontrol edildi [9].

\subsection{Metil parationun IC $C_{50}$ değerlerinin bulunmast}

$\mathrm{Bu}$ bileşiğin $\mathrm{IC}_{50}$ değerini bulmak için, $2 \mathrm{mM}$ paraoksan substratı ile çalışıldı. Pestisit çözeltisinden ise değişik hacimlerde alınarak toplam $1,05 \mathrm{ml}$ ' lik bir reaksiyon hacmi oluşturuldu. Önce inhibitörsüz ortamda enzim aktivitesi bulundu. Bu değer \%100 aktivite olarak kullanıld. Daha sonra optimum $\mathrm{pH}$ ve sıcaklıkta $0,05 \mathrm{ml}$ enzim çözeltisi alınıp $1 \mathrm{ml}$ (tampon + substrat + pestisit) çözeltisine çabuk bir şekilde eklendikten sonra 412 nm' de bir dakikada absorbans da meydana gelen değișme okundu. Elde edilen absorbans değerlerinden \% aktiviteler hesaplandı. \% Aktivite -[I] grafikleri çizildi.

\section{Sonuç ve tartışma}

Çalışmamızda, detoksifikasyon ve antioksidan aktivitesi ile metabolizmada önemli fizyolojik fonksiyona sahip PON1 enziminin HEK tekniği ile saflaştırılması gerçekleştirilmiş ve saflık kontrolü elektroforez ile yapılmıştır. PON1'in molekül ağırlığı yaklaşık $43 \mathrm{kDa}$ olarak tek bant şeklinde SDS-PAGE jelinde gözlenmiştir. (Şekil 1). Elde edilen bu sonuç literatürdeki sonuçlar ile uyumludur [7]. 


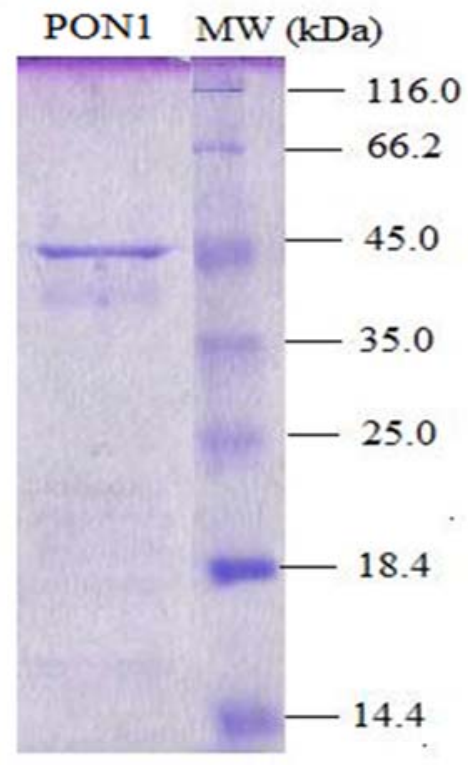

Şekil 1. PON1 enziminin SDS-PAGE görüntüsü.

Saflaştırma basamaklarının her bir aşamasında enzim aktiviteleri ve protein tayinleri yapıldı. Bu veriler kullanılarak söz konusu enzimin saflaştırma tablosu oluşturuldu. (Tablo 1). Tablo'da görüldüğü gibi 663 kat saflaştırma elde edildi. PON1 enziminin HEK yöntemi ile saflaştırılması ilk olarak Sinan ve arkadaşları tarafından yapılmıştır ve bu enzim 227 kat saflaştırılmıştır [7]. Yapılan bir diğer çalışmada Sepharose-4B-Ltirozin-1-naftilamin jeli modifiye edilmiş ve saflaştırma işlemi sırasında, ek olarak uygulanan iki basamak sonucunda enzim 302 kat saflaştırılmıştır [10]. Basit kromatografik yöntemler kullanılan bir başka çalışmada iyon değişim ve jel filtrasyon kromatografisi kullanılırken enzim yaklaşık 225 kat saflaştırılmıştır [11].

Tablo 1. PON1 enziminin saflaştırma tablosu.

\begin{tabular}{|l|l|l|l|l|l|l|}
\hline $\begin{array}{l}\text { Saflaştırma } \\
\text { Basamağ } 1\end{array}$ & $\begin{array}{l}\text { Hacim } \\
(\mathrm{ml})\end{array}$ & $\begin{array}{l}\text { Aktivite } \\
(\mathrm{U} / \mathrm{ml})\end{array}$ & $\begin{array}{l}\text { Protein } \\
(\mathrm{mg})\end{array}$ & $\begin{array}{l}\text { Spesifik Aktivite } \\
(\mathrm{U} / \mathrm{mg})\end{array}$ & \% Verim & $\begin{array}{l}\text { Saflaştırma } \\
\text { Derecesi }\end{array}$ \\
\hline Serum & 30 & 915 & 1015 & 0,90 & 100 & - \\
\hline AMS & 10 & 498 & 396 & 1,26 & 54 & 1,4 \\
\hline HEK & 2 & 132 & 0,221 & 597 & 14 & 663 \\
\hline
\end{tabular}

Çalışmamızın diğer aşamasında saf enzim üzerine metil paration zirai ilacının

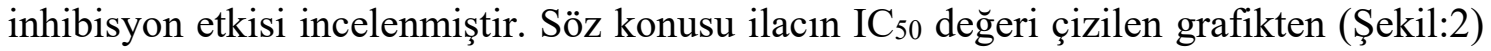
1,41 mM bulunmuştur. Enzimatik aktivitenin inhibisyonu üç farklı sebepten dolayı son derece önemli bir konudur; 1-biyolojik sistemlerde başlı başına bir kontrol mekanizmasıdır, 2- birçok ilaç ve zehirli bileşikler mekanizmalarını bu yolla gerçekleştirir, 3-inhibisyon olayı aynı zamanda enzimlerin etki mekanizmasının aydınlatılmasında oldukça önemlidir. 


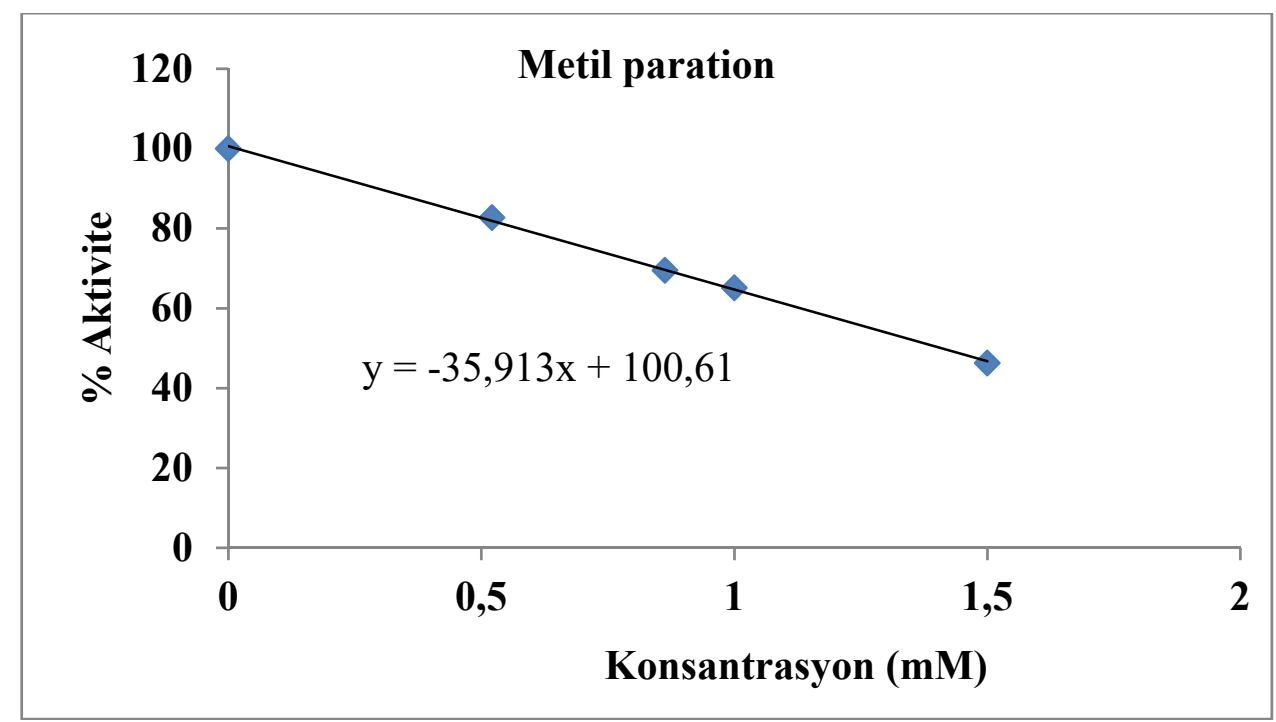

Şekil 2. İnhibisyon grafiği.

Çoğu pestisitler verimi artırma amacıyla tarımcılıkta kullanılır. Bu kimyasalların kullanımı ekinlerin gelişimine pozitif etki göstermelerine rağmen, bazı pestisitler, kalıntıları, metabolitleri ve/veya atıkları çevre üzerine umulmayan ters etkilere sebep olabilir [12]. Pestisitler, balık yemleri, dezenfektanlar gibi kullanımlarının yanı sıra tarımda verimi etkileyen zararlı bitki, hayvan ya da mikroorganizmalara karşı savaşta da önemli bir yere sahiptirler. Ancak bu faydalarına rağmen pestisitler insan sağlığına zararlı pek çok etkiye de sahiptirler [13]. Yüksek nörotoksik tarımsal kimyasal özellikleriyle bilinen çok yaygın bir pestisit olan metil paration, böcek haşerelerini yok etmek için dünya çapında yaygın olarak kullanılmaktadır. İnsan sağlığını içeren çevre, topraktaki kalıntıları nedeniyle ölümcül tehlikesiyle karşı karşıyadır [14].

\section{Kaynaklar}

[1] Azarsız, E., Sözmen, E.Y., Paraoksonaz ve klinik önemi, Türk Biyokimya Dergisi, 25(3), 109-119, (2000).

[2] Durrington, P.N., Mackness, B., Mackness, M.I., Paraoxonase and atherosclerosis. Arteriosclerosis, Thrombosis, And Vascular Biology, 21(4), 473-480, ( 2001).

[3] Ng, C. J., D. M. Shih, S. Y. Hama, N. Villa, M. Navab, and S. T. Reddy, The paraoxonase gene family and atherosclerosis, Free Radical Biology and Medicine, 38(2), 153-163, (2005).

[4] Gencer, N., Paraoksonaz Q ve R izoenzimlerinin saflaştırılması ve bazı çevre kirleticilere karşı afinitesinin araştırılması, Doktora Tezi, Balıkesir Üniversitesi, Fen Bilimleri Enstitüsü, Balıkesir, (2008).

[5] Dalkılıç, S., Metil paration ile muamele edilen sıçan dokularında sülfidril grubu konsantrasyonu değişimlerinin tespit edilmesi, Yüksek Lisans Tezi, Mustafa Kemal Üniversitesi, Fen Bilimleri Enstitüsü, (2006).

[6] Gan, K.N., Smolen A., Eckerson HW., La Du BN., Purification of human serum paraoksonase/arylesterase, evidence for one esterase catalyzing both activities, Drug Metabolism and Disposition, 19(1) , (1991), 100-6 
[7] Sinan, S., Kockar, F., Arslan, O., Novel purification strategy for human PON1 and inhibition of the activity by cephalosporin and aminoglikozide derived antibiotics. Biochimie, 88(5), 565-574, (2006).

[8] Bradford M., A rapid and sensitive method for the quantition of microgram quantities of protein utilizing the principle of protein-dye binding, Analytical Biochemistry, 72, 248-254, (1976).

[9] Laemmli, D. K., Cleavage of structural proteins during in assembly of the head of bacteriohhoge T4, Nature, London, 227, 680, (1970).

[10] Ekinci, D., Şentürk, M., Beydemir, Ş., Küfrevioğlu, Ö. İ., Supuran, C., T., An alternative purification method for human serum paraoxonase 1 and its interactions with sulfonamides" Chemical Biology \& Drug Design, 76, 552558, (2010).

[11] Ekinci, D., Beydemir, Ş., Ateş, O., In vitro effects of dexamethasone on human serum paraoxonase-1 (PON1) activity, Hacettepe Journal of Biology and Chemistry, 37(3), 197-205, (2009).

[12] Isik, S., Kockar, F., Ozensoy, O., Arslan, O., Differential in vitro effects of some pesticides on CA activities from some freshwater and seawater fish erythrocytes, Fresenius Environmental Bulletin, 13(1), 25-29, (2004).

[13] Karakoç, Ö., Nakiboğlu, N., Ditiyokarbamat pestisitleri ve tayin yöntemleri, Balıkesir Üniversitesi, Fen Bilimleri Enstitüsü Dergisi, 12(1), 112-135, (2010).

[14] Pattanayak, S., Chakraborty, S., Biswas, S., Chattopadhyay, D., Chakraborty, M., Degradation of methyl parathion, a common pesticide and fluorescence quenching of Rhodamine $\mathrm{B}$, a carcinogen using $\beta$-d glucan stabilized gold nanoparticles. Journal of Saudi Chemical Society, 22(8), 937-948, (2018). 